\title{
R17 - ENSAIO REAL TRIPLEX PARA HBV E DENGUE, VISANDO AMPLIAÇÃO DE ALVOS DO KIT NAT HIV/HCV BIO-MANGUINHOS
}

\author{
Autores: Antonio G. P. Ferreira ${ }^{1}$; Elisabete Andrade $^{1}$; Daniele Rocha ${ }^{1}$; Marcela \\ Fontana $^{1}$; Patrícia Alvarez ${ }^{1}$ \\ ${ }^{1}$ LATED/VDTEC/Bio-Manguinhos/Fiocruz;
}

Objetivo: Padronizar ensaio de diagnóstico molecular para detecção do vírus da Hepatite B (HBV) e Dengue na plataforma de PCR em Tempo Real. Atualmente, para triagem de doadores de sangue no Brasil, são realizados testes NAT para HIV e HCV. No entanto, visando ampliar a segurança transfusional, o teste para HBV e Dengue está sendo desenvolvido/padronizado, aproveitando as bases técnicas do modelo atual do Kit NAT de Bio-Manguinhos que contempla a detecção de HIV e HCV.

Metodologia: Os iniciadores e sondas usados na padronização dos ensaios foram das regiões S para HBV e 3'NCR para Dengue. Até o momento, para obtenção das provas de conceito, foram processadas amostras $\mathrm{HBV}$, positivas em ensaios sorológicos (HBsAg) e ensaios de quantificação de carga viral. Para Dengue, utilizamos 3 subtipos de vírus, de culturas de Dengue. Os testes foram realizados, individualmente, para cada alvo, permitindo a padronização da concentração de sondas e iniciadores. Para padronização do ensaio triplex, os dois alvos e a partícula calibradora (PC), como controle interno de reação, estão sendo ajustados em uma mesma reação.

Resultados: Para cada alvo (HBV e Dengue) foram testadas as fluorescências FAM e VIC e para PC, DYE3 (já estabelecida para o KIT NAT). A fluorescência FAM foi a melhor para os dois alvos, e a VIC não apresentou resultados satisfatórios em alguns subtipos de Dengue. Desta forma, adotou-se o FAM para Dengue e o VIC para HBV. Entretanto, foi necessária a otimização de concentração de sondas e iniciadores, para o uso da fluorescência VIC em HBV.

Conclusão: Os testes realizados indicam que a reação triplex por PCR em tempo real, para Dengue e HBV é bastante promissora. Visando padronizar e validar a reação para Dengue, e uma vez que amostras de cultura não refletem a complexidade de se amplificar/detectar, existe a real necessidade de se buscar amostras clínicas de Dengue 
(tipo 1 a 4). Serão necessários, também, estudos de avaliação da metodologia e plataforma de equipamentos frente a painéis internacionais, para confirmação das características técnicas do produto, e verificação da compatibilidade de aplicação nas rotinas de triagem de doadores nos Serviços de Hemoterapia. Dentre essas características técnicas serão determinados os níveis de sensibilidade, especificidade e reprodutibilidade, entre outros. 